\title{
The Effect of Chemical Composition and Thermal Sprayed Method on the Chromium and Tungsten Carbides Coatings Microstructure
}

\author{
Maria W. Richert, Borys Mikułowski, Pawel Pałka, Agnieszka Hotloś, Malgorzata Perek-Nowak \\ Faculty of Non-Ferrous Metals, AGH, University of Science \& Technology, Kraków, Poland. \\ Email: mrichert@agh.edu.pl
}

Received September $25^{\text {th }}, 2012$; revised October $27^{\text {th }}, 2012$; accepted November $4^{\text {th }}, 2012$

\begin{abstract}
The microstructure, phase consistence and microhardness of thermal sprayed coatings were investigated. The tungsten and chromium carbide coatings and also composite $\mathrm{NiCrSiB}$ coating were analyzed. The microstructure of coatings were observed by using optical microscopy (MO), scanning electron microscopy (SEM) and transmission electron microscopy (TEM). Almost equiaxial carbide particles settled inside the surrounded material of coating were found. The cracks propagating thorough the particles and along boundaries between the particles and surrounded material were observed. This phenomenon was connected with the porosity of coatings. The decarburization process was detected in coatings by phase composition investigation using X-ray method. The decarburization process was the reason due to which beside initial $\mathrm{Cr}_{3} \mathrm{C}_{2}$ the $\mathrm{Cr}_{7} \mathrm{C}_{3}$ and $\mathrm{Cr}_{23} \mathrm{C}_{6}$ particles were found. In the tungsten coatings beside the initial WC carbides the $\mathrm{W}_{2} \mathrm{C}$ ones were found.
\end{abstract}

Keywords: Thermal Spraying Methods; Coatings; Chromium and Tungsten Carbides; Composite; Microstructure; Microhardness; Porosity

\section{Introduction}

The coating should provide a good balance between the abradability and the erosion resistance. The abradability and erosion resistance are the most important properties of the coating. Especially, the research on the erosion wear behavior of the coatings has not been much reported. Because of high porosity and much non-metal phase in the coating its erosion wear rule and behavior can be different from those of bulk material and some coatings. The thermal spraying coatings are the effective wear resistant protection preserving the surface of the different appliances, machines and plants in the industry conditions $[1,2]$. One of the possible application is the deposition of coatings on the industry fan blades [3]. The tungsten and chromium carbides coatings are especially useful in the hard conditions of fun blades exposition on the wood and MDF dust, iron fillings and other kinds of dust. The microstructure of the different chemical composition of carbides coatings deposited by plasma spraying (PS) and High Velocity Oxygen Fuel (HVOF) thermal spray processes were tested and investigated. The special attention was paid to the production of the nanometric microstructure of coatings, which ensure not only high hardness but also good smoothness of the coatings surface [4].

In the paper the microstructure, phase consistence and hardness of thermal sprayed coatings were investigated.

\section{Investigated Methods}

The High-Velocity Oxy-Fuel spraying (HVOF) and Plasma Sprayed techniques were used for coats spraying. The HVOF deposition parameters are presented in the Table 1.

The plasma spraying parameters are presented in Table 2. The thickness of HVOF coatings was found of about $300+80 \mu \mathrm{m}$. In the case of the plasma spraying samples the thickness of coating was found of about 300 $+/-20 \mu \mathrm{m}$. The Table 3 contained chemical composition of seven investigated in the work coatings.

The composition of coatings consisting from $\mathrm{NiCrBSi}$, chromium and tungsten carbide and its mixtures or with the carbides or with the introduction of $\mathrm{CrC}, \mathrm{Ni}$, Co and $\mathrm{Cr}$ powders. The coatings were sprayed at the AlSi substrate. The WC-Co-Cr coating (sample No. 1), WC-Co (No. 2), WC-Co-CrC-Ni (No. 4) composite coating NiCrBSi (No. 6) and $\mathrm{Cr}_{3} \mathrm{C}_{2}$ coating with the intermediate layers of NiAl (sample No. 7) are sprayed by using High Velocity Oxy-Fuel method The spraying distance 
Table 1. HVOF spraying deposition parameters.

\begin{tabular}{ccccc}
\hline \multicolumn{5}{c}{ HVOF method } \\
\hline $\mathrm{O}_{2}$ & Kerosene & $\mathrm{N}_{2}$ & Distance & Powder \\
\hline $1 / \mathrm{min}$ & $1 / \mathrm{h}$ & $1 / \mathrm{min}$ & $\mathrm{mm}$ & $\mathrm{g} / \mathrm{min}$ \\
\hline 944 & 25.5 & 9.5 & 370 & 92 \\
\hline
\end{tabular}

Table 2. Plasma spraying deposition parameters.

\begin{tabular}{cccc}
\hline \multicolumn{4}{c}{ Plasma spraying method } \\
\hline $\mathrm{Ar}$ & Voltage & Current & Distance \\
\hline $1 / \mathrm{h}$ & $\mathrm{V}$ & $\mathrm{A}$ & $\mathrm{mm}$ \\
\hline 3000 & 52 & 500 & 90 \\
\hline
\end{tabular}

Table 3. The chemical composition of deposited coatings.

\begin{tabular}{ccc}
\hline No. & Chemical composition of coating & Deposition method \\
\hline 1 & WC-Co-Cr & HVOF \\
2 & WC-Co & HVOF \\
3 & WC-Co $+15 \% \mathrm{NiCrBSi}$ & Plasma spraying \\
4 & WC-Co-CrC-Ni & HVOF \\
5 & $\mathrm{Cr}_{3} \mathrm{C}_{2}-\mathrm{NiCr}$ & Plasma spraying \\
6 & $\mathrm{NiCrBSi}_{3}$ & HVOF \\
7 & $\mathrm{Cr}_{3} \mathrm{C}_{2}-\mathrm{NiCr}$ & HVOF \\
\hline
\end{tabular}

of $370 \mathrm{~mm}$ and gun speed $35 \mathrm{~m} / \mathrm{min}$ were used. The special vibratory disc feeder CPF-2 Thermico firm, allowing feeding of powders with very low granulation $10-2 \mu \mathrm{m}$ with the precision. $\pm 2 \%$ was used. The sample No. 3, consisting from the mixture of $\mathrm{WC}-\mathrm{Co}+\mathrm{NiCrBSi}$ and sample No. $5 \mathrm{Cr}_{3} \mathrm{C}_{2}-\mathrm{NiCr}$ are deposited by the plasma spraying method. The plasma sprayed $80 \% \mathrm{Cr}_{3} \mathrm{C}_{2}-$ $20 \% \mathrm{NiCr}(\mathrm{wt} \%)$ coats were prepared by MIM40 device. The argon $3000 \mathrm{l} / \mathrm{h}$ and hydrogen $873 \mathrm{l} / \mathrm{min}$ were used for melting powders particles before their impact onto the substrate. The spraying distance of $90 \mathrm{~mm}$ and gun speed $25 \mathrm{~m} / \mathrm{min}$ were used. The deposition of coatings was performed in enterprise Plasma System S. A., Siemianowice Śląskie, Poland. The following powders were using for HVOF and Plasma Spraying deposition: 95\% (WC-Co 88-12-30 + $5 \mu \mathrm{m}$; WC $1-0.5 \mu \mathrm{m}$, agglomerating and sintering $)+5 \%(\mathrm{Ni} 17 \mathrm{Cr} 4 \mathrm{Fe} 4 \mathrm{Si} 3.5 \mathrm{~B} 1 \mathrm{C}$ speroidal, gas atomized, nanopowder); 73\%(WC) $+20(\mathrm{CrC})$ $+7 \% \mathrm{Ni}-45+15$ agglomerating and sintering; $\mathrm{WC}-1$ $\mu \mathrm{m}$; $\mathrm{CrC} 1 \mu \mathrm{m}+5 \%(\mathrm{Ni} 17 \mathrm{Cr} 4 \mathrm{Fe} 4 \mathrm{Si} 3.5 \mathrm{~B} 1 \mathrm{C})$ speroidal, gas atomized, nanopowder $3 \%(\mathrm{WC})+20\left(\mathrm{Cr}_{3} \mathrm{C}_{2}\right)+7 \% \mathrm{Ni}$ $-45+15$ agglomerating and sintering, WC $1 \mu \mathrm{m} ; \mathrm{Ni}$ $17 \mathrm{Cr} 4 \mathrm{Fe} 3.5 \mathrm{~B} 4 \mathrm{Si1C}$, grain size: $-20+2 \mu \mathrm{m}, 86 \% \mathrm{WC}-$
$10 \% \mathrm{Co}-4 \% \mathrm{Cr}$, grain size: $10+2 \mu \mathrm{m}$; $\mathrm{WC}$, grain size: $0.5-0.2 \mu \mathrm{m}$. The microstructure of all coatings was studied by Olympus GX50 optical microscopy. Thin foils prepared from samples by the cross section technique were observed by JEOL 2010 ARB transmission electron microscopy with the Energy Disperse Spectrometer (EDS) for identification of chemical composition in microareas of layers. The microhardness of coats was measured by using PMT3 microhardness tester at load $200 \mathrm{~g}$. The samples to light microscopy observations were polished mechanically applied Struers equipment and technique. They were grinded, than polished in diamond pastes and in the suspension OPS. Thin foils, for TEM investigations, were prepared from cross sections by cutting grinding and ion sputtering, using Struers and Gatan instruments.

\section{Results}

It was found that the hardness of the tungsten carbide coatings was higher than the chromium carbide coatings (Figure 1). The highest microhardness show $\mathrm{WC}-\mathrm{Co}-\mathrm{Cr}$ coating deposited by $\mathrm{HVOF}$ and the lowest $\mathrm{Cr}_{3} \mathrm{C}_{2}-\mathrm{NiCr}$ deposited by plasma spraying method. The results relate to the microstructure and phase composition of the coatings.

The microstructure of coatings sprayed by HVOF process, investigated by transmission electron microscopy (TEM) exhibited nanometric features (Figures 2 and 3). The plasma spraying one showed larger granules size (Figure 4).

Optical microscopy investigations exhibited the numerous, almost equiaxial carbides inside the $\mathrm{WC}-\mathrm{Co}-\mathrm{Cr}$ coating deposited by HVOF (Figure 5).

The good adhesion was found between the substrate and coating. The coatings are of high porosity, which is visible as black places in Figure 5. The microstructure of $\mathrm{Cr}_{3} \mathrm{C}_{2}-\mathrm{NiCr}$ coating deposited by plasma spraying process is presented in Figure 6. Similarly as in the case of

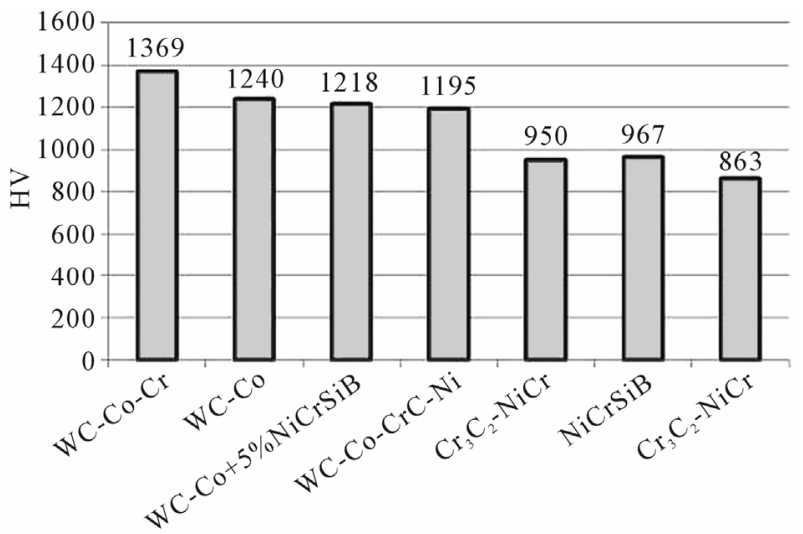

Figure 1. Microhardness of the deposited coatings. 


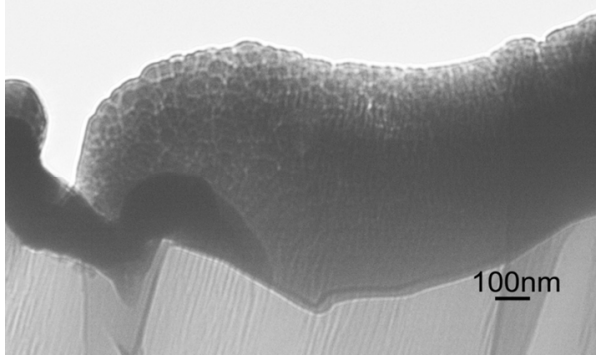

Figure 2. WC-Co-Cr coating, TEM, sample No. 1, HVOF.

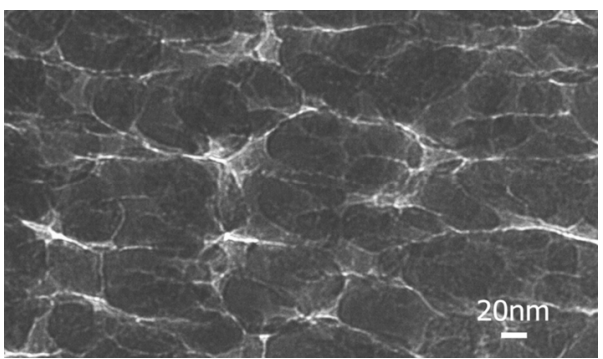

Figure 3. WC-Co-CrC-Ni, TEM, sample No. 4, HVOF.

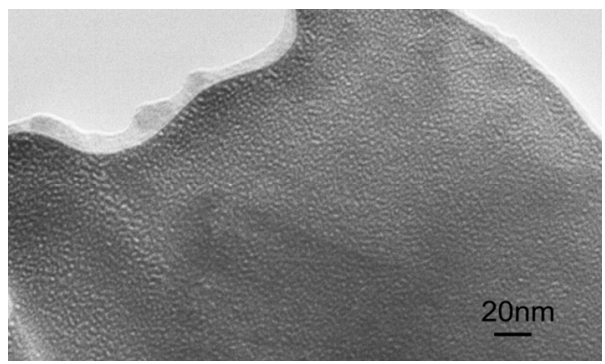

Figure 4. $\mathrm{Cr}_{3} \mathrm{C}_{2}-\mathrm{NiCr}$, TEM, sample No. 5, plasma spraying.

tungsten carbides also the almost equiaxial $\mathrm{Cr}_{\mathrm{x}} \mathrm{C}_{\mathrm{y}}$ particles were found inside the $\mathrm{Ni}$ surrounded material, deposited at AlSi substrate. The coating show considerable porosity.

More details of microstructure of coatings was found by scanning electron microscopy (SEM) observations. The distribution and morphologies of WC-Co-Cr carbides is presented in Figure 7. The pores exist generally next to carbide and surrounded material boundaries. Some cracks propagate through the particles indicating fragility of carbides. High microhardness contribute to this phenomenon.

The similar, as in the case of tungsten carbide coatings, porosity was found in $\mathrm{Cr}_{3} \mathrm{C}_{2}-\mathrm{NiCr}$ coating (Figure 8). It is characteristic some difference in the carbides size. Next the large carbides of $10 \mu \mathrm{m}$ in diameter the smallest ones with $1 \mu \mathrm{m}$ or much below are situated (Figures 7 and 8).

The existence of $\mathrm{Cr}_{3} \mathrm{C}_{2}, \mathrm{Cr}_{7} \mathrm{C}_{3}, \mathrm{Cr}_{23} \mathrm{C}_{6}, \mathrm{~W}_{2} \mathrm{C}$ and $\mathrm{WC}$ carbides was found inside the investigated coatings $\mathrm{It}$ is generally considered that $\mathrm{Cr}_{7} \mathrm{C}_{3}, \mathrm{Cr}_{23} \mathrm{C}_{6}$ carbides are formed through decarburization of $\mathrm{Cr}_{3} \mathrm{C}_{2}$ carbides.

In $\mathrm{Cr}_{3} \mathrm{C}_{2}$ coating deposited by plasma spraying and by

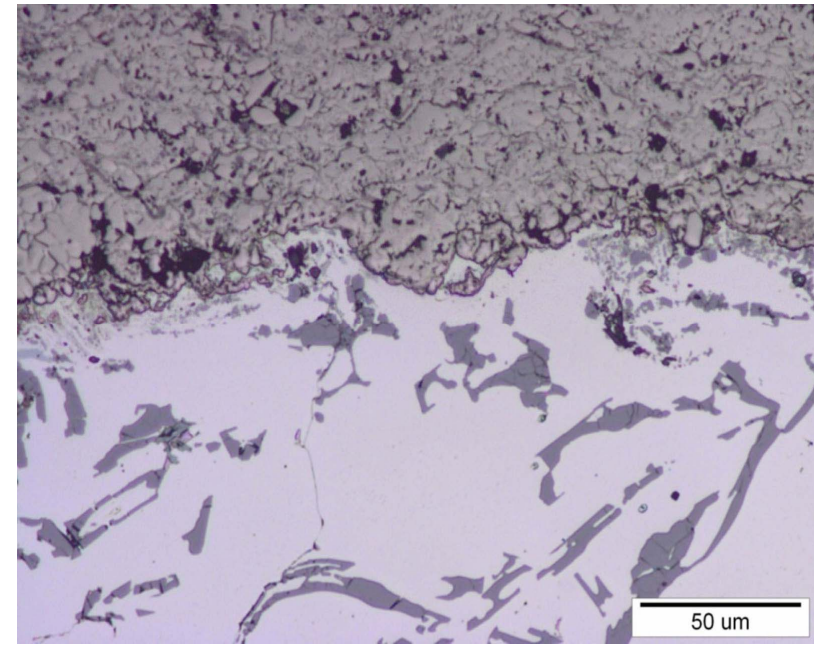

Figure 5. WC-Co-Cr deposited by HVOF (MO).

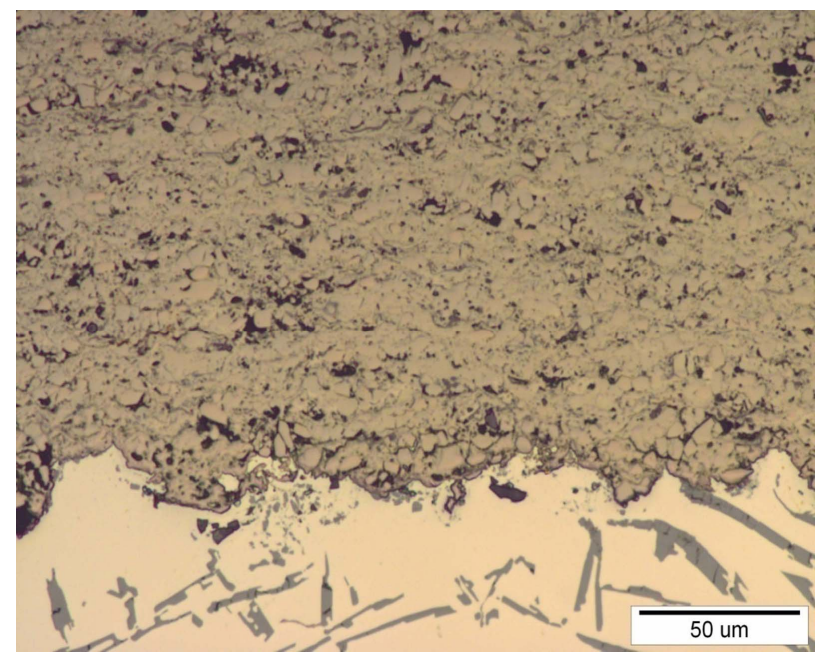

Figure 6. $\mathrm{Cr}_{3} \mathrm{C}_{2}$-NiCr deposited by plasma spraying process (MO).

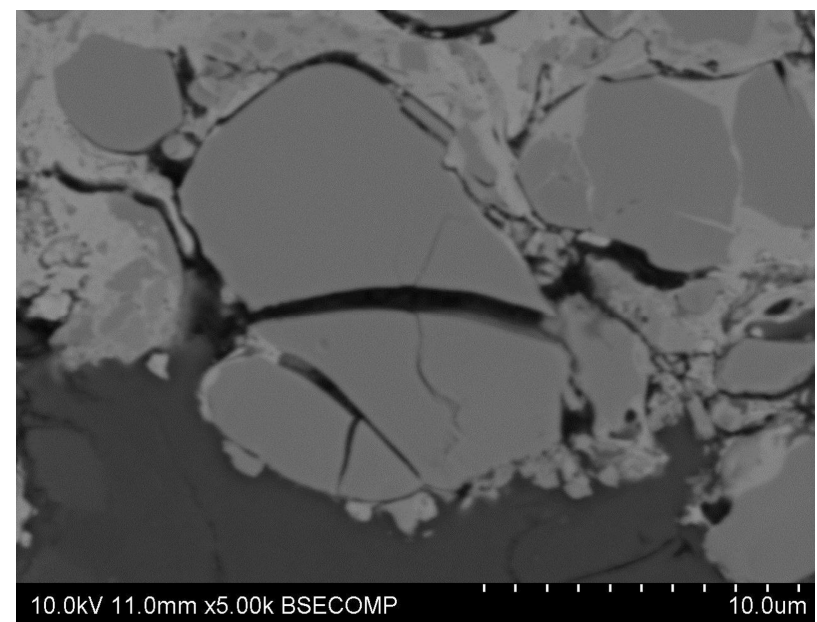

Figure 7. Microstructure of WC-Co-Cr deposited by HVOF (SEM). 


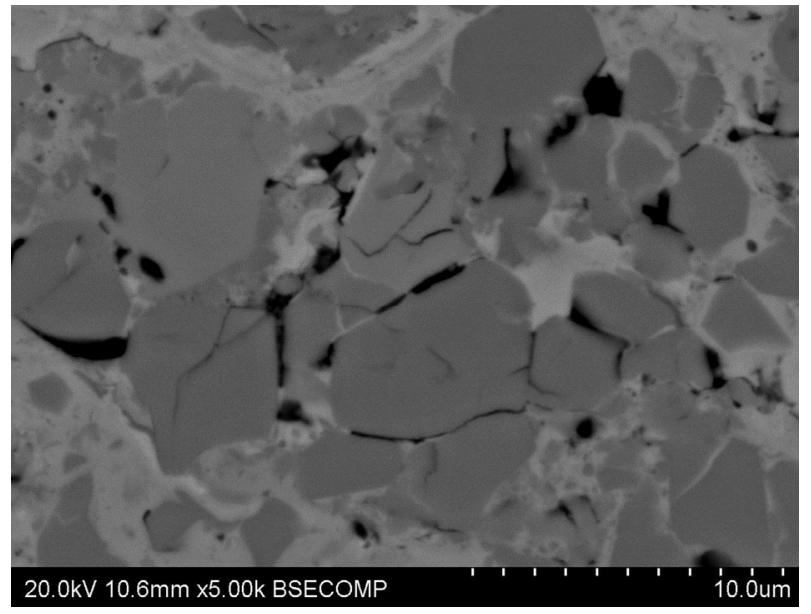

Figure 8. $\mathrm{Cr}_{3} \mathrm{C}_{2}-\mathrm{NiCr}$ deposited by plasma spraying process (SEM).

HVOF method $\mathrm{Cr}_{3} \mathrm{C}_{2}, \mathrm{Cr}_{7} \mathrm{C}_{3}$ and $\mathrm{Cr}_{23} \mathrm{C}_{6}$, carbides were found (Figures 9 and 10). The presence of $\mathrm{Cr}_{3} \mathrm{C}_{2}$ carbides evidence some stability of the initial material and proper parameters of deposition process, preserving complete decarburization of chromium carbide. The $\mathrm{Cr}_{23} \mathrm{C}_{6}$ and $\mathrm{Cr}_{7} \mathrm{C}_{3}$ carbides resulted from the decarburization of $\mathrm{Cr}_{3} \mathrm{C}_{2}$ owing to overheating of the particles during the spraying of the carbides slowly form below $300^{\circ} \mathrm{C}$ and rapidly between $300^{\circ} \mathrm{C}$ and $600^{\circ} \mathrm{C}$. This correlates with the hardness behavior between $20^{\circ} \mathrm{C}$ and $600^{\circ} \mathrm{C}$. X-ray diffraction data indicate the formation of a $\mathrm{Cr}_{7} \mathrm{C}_{3}$ bulk phase above $600^{\circ} \mathrm{C}$ and $\mathrm{a}_{23} \mathrm{C}_{6}$ bulk phase above $700^{\circ} \mathrm{C}$. This agglomeration or precipitation of the carbides results in reduction of the film hardness [5].

The tungsten carbide coatings phase composition is presented in Figures 11 and 12. The $\mathrm{WC}$ and $\mathrm{W}_{2} \mathrm{C}$ carbides were found. The existence of $\mathrm{W}_{2} \mathrm{C}$ carbides testify about the decarburization during deposition process. The WC-based materials are characterized by phase transformations during the spray process (formation of $\mathrm{W}_{2} \mathrm{C}$ or $(\mathrm{W}, \mathrm{Cr})_{2} \mathrm{C}$ and metallic tungsten) which result in an increase in density [6]. The formation of $\mathrm{W}_{2} \mathrm{C}$ and metallic tungsten is most important. In the case of Cr-alloyed compositions (W,Cr) $)_{2} \mathrm{C}$ with the structure of $\mathrm{W}_{2} \mathrm{C}$ appears, as can be proposed from the shift of the lattice parameters compared with the $\mathrm{W}_{2} \mathrm{C}$-standard. The formation of these phases leads to significant deviations in the composite density. $\mathrm{W}_{2} \mathrm{C}\left(17.2 \mathrm{~g} / \mathrm{cm}^{3}\right)$ and metallic tungsten $\left(19.3 \mathrm{~g} / \mathrm{cm}^{3}\right)$ have significantly higher densities than WC $\left(15.7 \mathrm{~g} / \mathrm{cm}^{3}\right)$. Due to the undetermined coating compositions their theoretic densities cannot be obtained.

\section{Summary}

The results show that the structure of the plasma sprayed and deposited by HVOF process coatings is complicated.

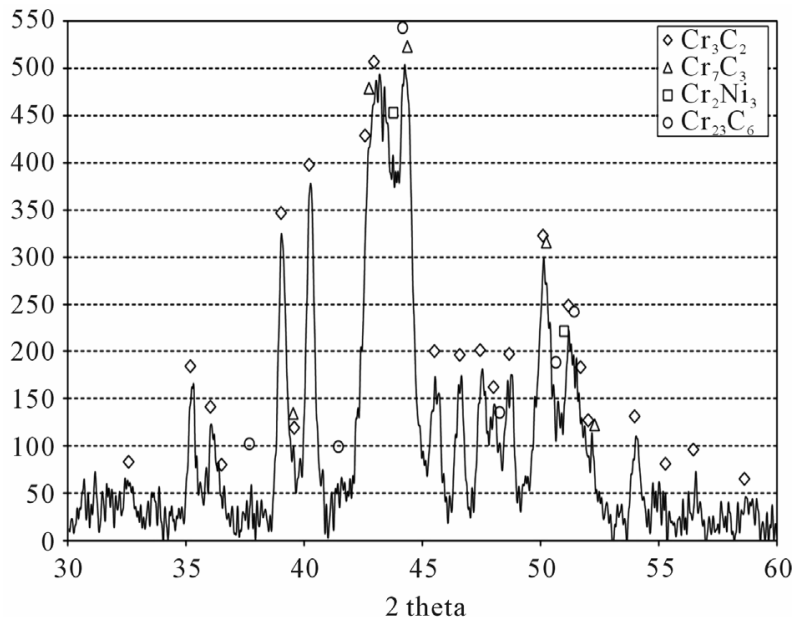

Figure 9. X-ray result of phase consistence investigation of $\mathrm{Cr}_{3} \mathrm{C}_{2}$-NiCr coating deposited by plasma spraying method.

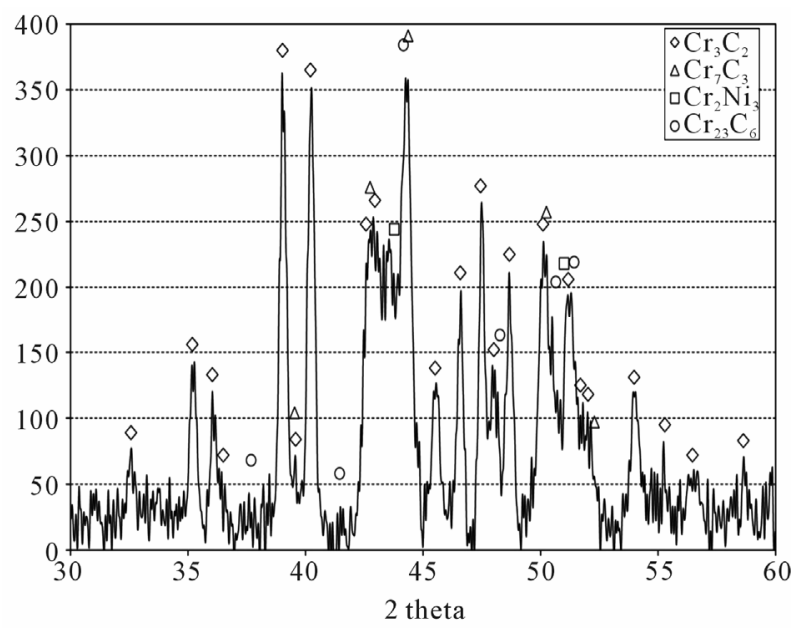

Figure 10. X-ray result of phase consistence investigation of $\mathrm{Cr}_{3} \mathrm{C}_{2}$-NiCr coating deposited by HVOF.

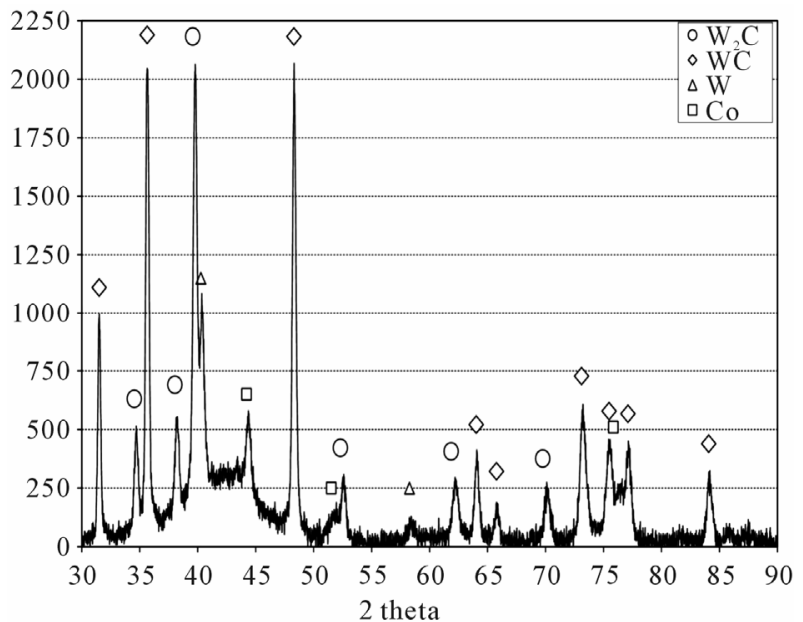

Figure 11. X-ray result of phase consistence investigation of WC-Co coating deposited by HVOF. 


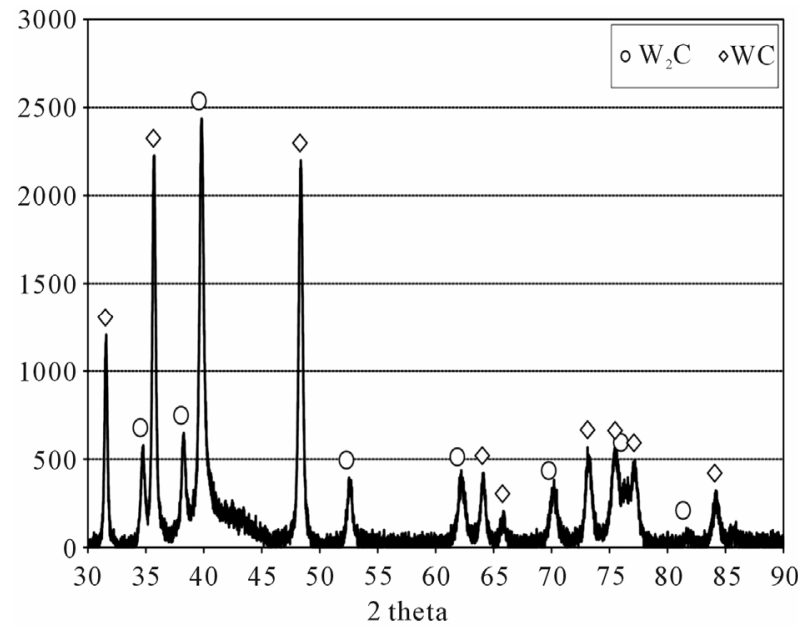

Figure 12. X-ray result of phase consistence investigation of WC-Co coating deposited by plasma spraying method.

The carbide particles are the main microstructure inside the binder. Besides this the pores and oxides exist inside coatings.

The main structure of the tungsten coatings is composed of WC grains with a mean particle size of $35 \mathrm{~nm}$. In some regions, the structure is composed of WC grains with a mean particle size of $10 \mathrm{~nm}$ embedded in an amorphous matrix, which is formed by melting of the WC-Co powders. In the case of $\mathrm{Cr}_{3} \mathrm{C}_{2}-\mathrm{NiCr}$ coatings they consist from almost equiaxial carbides.

$\mathrm{X}$-ray diffraction analysis confirmed the presence of a larger percentage of WC (Figures 11 and 12). This result was expected due to the higher flame velocity and lower flame temperature of the process, which would limit the decomposition process. X-ray diffraction also indicated a substantial amount of $\mathrm{W}_{2} \mathrm{C}$. The X-ray diffraction showed a broad maxima in the $40-48$ two theta range, which is characteristic of microcrystalline or amorphous materials. The cobalt and excess carbon is probably present in the coatings in an amorphous state.

The carbides $\mathrm{Cr}_{7} \mathrm{C}_{3}$ and $\mathrm{Cr}_{23} \mathrm{C}_{6}$ might be also present according to the reported results through $\mathrm{X}$-ray diffraction analyses. The $\mathrm{Cr}_{7} \mathrm{C}_{3}$ and $\mathrm{Cr}_{23} \mathrm{C}_{6}$ resulted from the decarburization of $\mathrm{Cr}_{3} \mathrm{C}_{2}$ owing to overheating of the particles during the thermal spraying process. $\mathrm{Cr}_{7} \mathrm{C}_{3}$ is formed directly from the decarburization of $\mathrm{Cr}_{3} \mathrm{C}_{2}$ due to to extensive heating to melting state. The solution of melted carbide raises carbon content in the matrix and subsequently the matrix will be saturated by carbon. During solidification of the molten matrix phase, the oversaturated carbon will be precipitated in the form of chromium carbide again. The presence of $\mathrm{Cr}_{7} \mathrm{C}_{3}$ in the as-sprayed coating cannot be proven just by X-ray diffraction techniques because its main diffraction peaks coincide with the lines referring to the $\mathrm{Cr}_{3} \mathrm{C}_{2}$ phase, therefore it is only possible to suppose that it exists [7].
The tungsten deposits are harder than $\mathrm{Cr}_{3} \mathrm{C}_{2}$ deposits and present a low porosity to determine the hardness of a coating.

\section{Conclusions}

The results of the present study on the chromium and tungsten carbide thermal sprayed coatings can be summarized as follows:

- Coatings exhibit high hardness with a high volume fraction of carbides being preserved during the thermal spraying proceses. Hardness of the tungsten coatings were higher than those of the chromium coatings.

- The investigated chromium and tungsten carbides coatings depending on the method of deposition showed nanometric or micrometric features of microstructure.

\section{Acknowledgements}

The work was financially supported by polish project NR15 0001 06, and the Ministry of Higher Education and Science/AGH University of Science and Technology, Kraków, Poland, grant number 11.11 .180 .255 is greatly acknowledged.

\section{REFERENCES}

[1] C. R. C. Lima and F. Camargo, "Thermal Spray 2003, Advancing the Science \& Applying the Technology," ASM International, 2003.

[2] J. M. Guilemany, N. Espallargas, P. H. Suegama and A. V. Benedetti, "Comparative Study of $\mathrm{Cr}_{3} \mathrm{C}_{2}$ - $\mathrm{NiCr}$ Coatings Obtained by HVOF and Hard Chromium Coatings," Corrosion Science, Vol. 48, No. 10, 2006, pp. 2998-3013. doi:10.1016/j.corsci.2005.10.016

[3] M. W. Richert, "The Wear Resistance of Thermal Spray the Tungsten and Chromium Carbides Coatings," Journal of Achievements in Materials and Manufacturing Engineering, Vol. 47, No. 2, 2011, pp. 177-184.

[4] H. Jianhong and J. M. Schoenung, "Nanostructured Coatings," Materials Science \& Engineering, Vol. A336, 2002, pp. 274-319.

[5] G. N. Salaita and G. B. Hoflund, "Dynamic SIMS Study of $\mathrm{Cr}_{3} \mathrm{C}_{2}, \mathrm{Cr}_{7} \mathrm{C}_{3}$ and $\mathrm{Cr}_{23} \mathrm{C}_{6}$," Applied Surface Science, Vol. 134, No. 1-4, 1998, pp. 194-196. doi:10.1016/S0169-4332(98)00246-3

[6] L.-M. Berger, S. Saaro, T. Naumann, M. Wiener, V. Weihnacht, S. Thiele and J. Suchanek, "Microstructure and Properties of HVOF-Sprayed Chromium Alloyed WC-Co and WC-Ni Coatings," Surface and Coatings Technology, Vol. 202, No. 18, 2008, pp. 4417-4421.

[7] G.-C. Ji, C.-J. Li, Y.-Y. Wang and W.-Y. Li, "Microstructural Characterization and Abrasive Wear Performance of HVOF Sprayed $\mathrm{Cr}_{3} \mathrm{C}_{2}-\mathrm{NiCr}$ Coating," Surface and Coatings Technology, Vol. 200, No. 24, 2006, pp. 6749-6757. doi:10.1016/j.surfcoat.2005.10.005 